\title{
Unfair tax competition influence on the development of the sustainable economy and international economic relations
}

\author{
Olga Sokolova, Nadezhda Goncharova*, and Pavel Lenov \\ Ural State University of Economics, Russian Federation
}

\begin{abstract}
The gist of this article boils down to the impact of unfair tax competition on the current state and further development of a sustainable economy and international economic relations. With the development of the world economy and international economic relations, the world community is faced with such an economic category as unfair tax competition or tax dumping. International tax competition or tax dumping is one of the most negative phenomena associated with the tax policy of states. To stimulate the inflow of investment in a particular country or region, governments of different jurisdictions resort to a special type of tax policy characterized by strong tax cuts. It is obvious that unfair tax competition consists of not only tax dumping, but also other advantages provided by the state. The most obvious of these benefits is high confidentiality for investors. The activities of offshore jurisdictions can not only cause significant damage to the economies of countries that are not able to apply tax dumping, but also provoke serious economic crises. Tax evasion is primarily due to the fact that economic agents prefer to register in offshore countries and pay taxes there. In this regard, offshore countries are quite rightly called the "dependents" of the world economy, since they are the ones who unreasonably use the public goods created by the onshore states. The article examines the impact of unfair tax competition on the current state and further development of the world economy and international economic relations. The policy of offshore countries is analyzed, the reasons, problems and prospects for the development of the international struggle against unfair tax competition are studied. Final positioning is formulated in the paper.
\end{abstract}

\section{Introduction}

With the development of the world economy and international economic relations, the world community is faced with such an economic category as unfair tax competition or tax dumping [1-11].

To stimulate the inflow of investment in a particular country or region, governments of different jurisdictions resort to a special type of tax policy characterized by strong tax cuts. It is obvious that unfair tax competition consists not only of tax dumping, but also other

\footnotetext{
${ }^{*}$ Corresponding author: nadin1325x@yandex.ru
} 
advantages provided by the state. The most obvious of these benefits is high confidentiality for investors.

These measures lead to a significant outflow of capital from other countries as a result of a decrease in the tax base and cause significant damage to the economies of developed countries, such as Western Europe and the United States.

Unfair tax competition is fine as long as offshore countries provide international companies with soft tax regimes and provoke an outflow of funds from onshore countries. So, in countries that do not provide tax benefits, the tax base is reduced, which automatically leads to a decrease in tax revenues of the state budget. As you know, tax revenues make up a significant part of the revenues of the budgets of the countries of the world. The quality and completeness of the fulfillment of its social functions by the state depends on budget revenues. Thus, unfair tax competition, on the one hand, brings foreign investment to one country and promotes development, and on the other hand, it cuts the budget of the second state and negatively affects the welfare of its population.

\section{Research materials and methods}

It should be understood that the tax policy of a country depends not only on its desire to attract investment, but also on the capabilities of the government, the economic system and even the social order. From this we can conclude that it is not possible to get rid of tax competition, and in particular from unfair tax competition.

However, if it is completely impossible to get rid of unfair tax competition, then states have already learned how to significantly reduce, limit and begin to control it.

For the first time, the concept of "unfair tax competition" and its signs were described in the Report of the Organization for Economic Cooperation and Development in 1998.

The results of the study provided in the Organization for Economic Cooperation and Development report identified the main features inherent in tax regimes that can potentially develop unfair tax competition (Table 1).

Table 1. Signs of tax regimes that have the potential to develop unfair tax competition

\begin{tabular}{|l|l|}
\hline \multicolumn{1}{|c|}{ Sign } & \multicolumn{1}{c|}{ Feature characteristic } \\
\hline income tax rate & $\begin{array}{l}\text { This feature should be considered in two stages. In the first stage, the nominal income tax } \\
\text { rate is considered, in the second stage - the effective income tax rate. The nominal rate is set } \\
\text { at the level of legislation and, as a rule, is the same for all tax residents (excluding the } \\
\text { provision of benefits, tax exemptions, etc.). The effective tax rate reflects the real tax } \\
\text { burden of the organization, while it can be much lower than the nominal rate due to the } \\
\text { established tax calculation methodology or to the implementation of tax planning measures. }\end{array}$ \\
\hline $\begin{array}{l}\text { Lack of } \\
\text { transparency }\end{array}$ & $\begin{array}{l}\text { The lack of transparency in this context is understood as a model of the tax regime in which } \\
\text { third countries do not have access to information about the country's tax system, primarily } \\
\text { about tax legislation and administration, as well as legislative provisions on non-disclosure } \\
\text { of information about beneficial owners and other information. }\end{array}$ \\
\hline $\begin{array}{l}\text { Information } \\
\text { exchange }\end{array}$ & $\begin{array}{l}\text { As part of international cooperation, countries can exchange information about their tax } \\
\text { residents in order to improve the quality of tax administration and the proper performance } \\
\text { of their duties. As a rule, the exchange of information is provided for by agreements on the } \\
\text { avoidance of double taxation and the prevention of tax evasion concluded between these } \\
\text { countries, or through the conclusion of a separate agreement on the exchange of } \\
\text { information. }\end{array}$ \\
\hline $\begin{array}{l}\text { - Based on the results of the study, additional factors were also identified that indirectly prove the existence of } \\
\text { the fact of unfair tax competition. } \\
\text { - artificial determination of the tax base; } \\
\text { - inconsistency with the principles of transfer pricing } \\
\text { - exemption from taxation of income received from foreign sources; } \\
\text { - the establishment of reduced tax rates on an individual basis; } \\
\text { - secrecy of information; } \\
\text { - availability of a wide network of agreements on avoidance of double taxation and prevention of tax evasion; } \\
\text { - the tax system is based on the concept of an unjustified tax benefit }\end{array}$ \\
\hline
\end{tabular}


Low-tax governments perceive unfair tax competition as a result of expanding capital markets as well as increasing trade liberalization. This is due to the emergence of closer ties between the economies of the countries of the world, the expansion of their borders by transnational corporations, the development of infrastructure, the application of measures aimed at creating additional jobs, etc. Many offshore zones have already recognized that it is not necessary to resort to tax dumping.

Thus, an offshore country with a developed infrastructure, a stable political system, a stable economy and a developed social sphere is able to gain its market share in cooperation with the Organization for Economic Cooperation and Development.

Some countries, in order to prevent unfair tax competition, go to the creation of certain economic groups. One of the most striking examples is the European Union. The main goal of creating associations of European states was the coordination of economic and social development, the formation of a single market for goods and services, a single customs and tax policy.

\section{Results and discussion}

As a result of the merger and the signing of a number of agreements, some countries suffered losses due to changes in tax policy, while others, on the contrary, were able to increase their income and become more attractive in the eyes of potential investors. To date, the European Union has not managed to completely defeat unfair tax competition, which is associated with the different rates of economic growth of the EU member states.

For a more complete understanding of the current situation, one should consider the size of income tax in European countries (table 2).

Table 2. Income tax in European countries

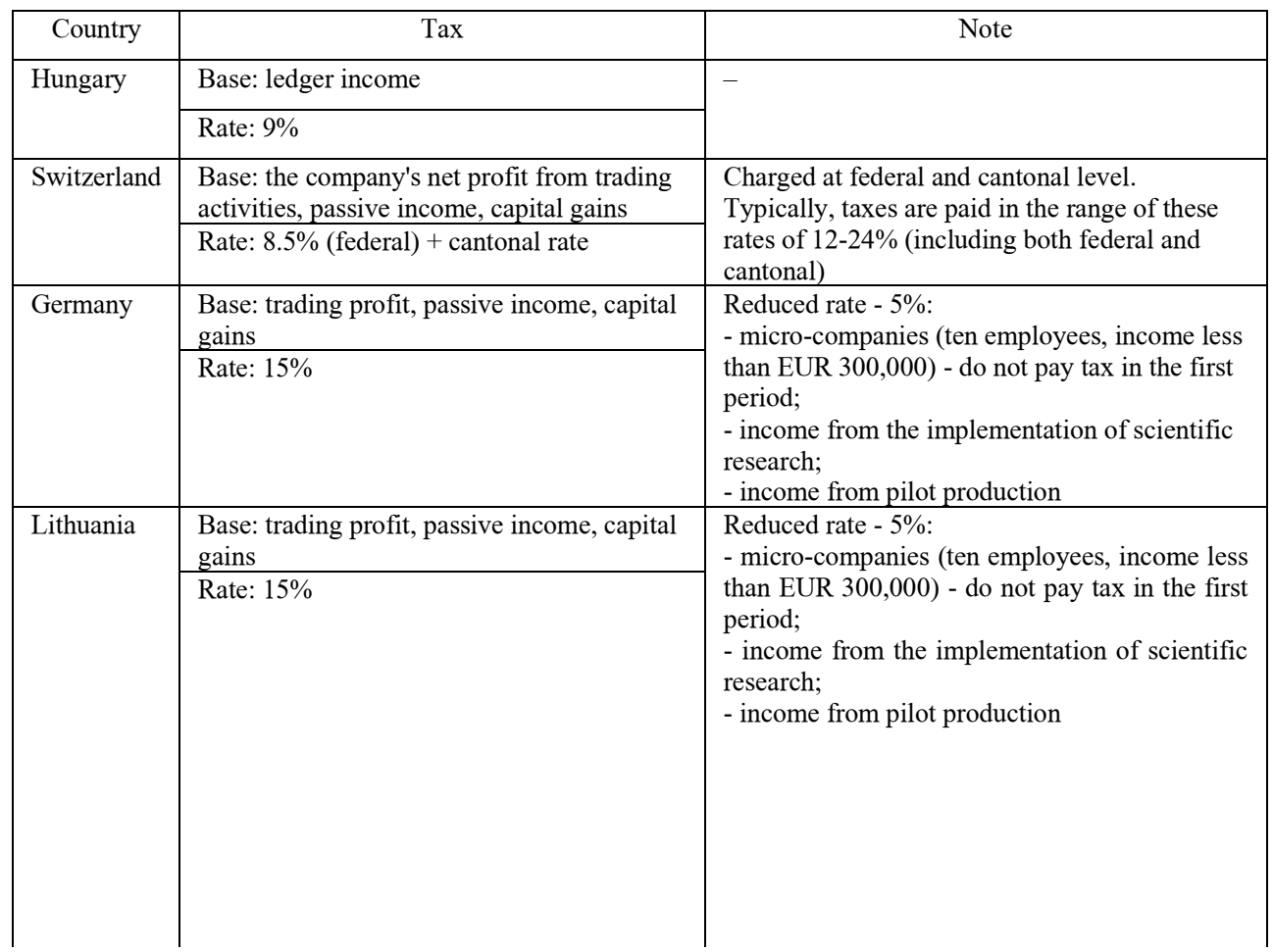


Table 2. Continued

\begin{tabular}{|c|c|c|}
\hline \multirow[t]{2}{*}{$\begin{array}{l}\text { Great } \\
\text { Britain }\end{array}$} & $\begin{array}{l}\text { Base: resident companies - profits from } \\
\text { trading activities, some non-trading income, } \\
\text { capital gains }\end{array}$ & \multirow[t]{2}{*}{$\begin{array}{l}25 \% \text { - for multinational companies using } \\
\text { fictitious agreements to divert profits abroad to } \\
\text { avoid taxation in the UK }\end{array}$} \\
\hline & $\begin{array}{l}\text { Rate: } 17 \% \text {. To date, a reduced rate } \\
\text { (previously } 19 \% \text { ) has been adopted by the } \\
\text { authorities for profits made after April } 1 \text {, } \\
2020 . \text { Those. will be effectively applied } \\
\text { only after a year, when the first companies } \\
\text { start paying taxes for the } 2020 \text { period }\end{array}$ & \\
\hline \multirow[t]{2}{*}{ Poland } & $\begin{array}{l}\text { Base: Profits earned from both trading } \\
\text { activities and capital gains }\end{array}$ & \multirow{2}{*}{$\begin{array}{l}9 \% \text { - on income from return on capital. } \\
\text { For small taxpayers or taxpayers who are just } \\
\text { starting a business and whose revenue is less } \\
\text { than } 1.2 \text { million PLN }\end{array}$} \\
\hline & Rate: $19 \%$ & \\
\hline \multirow[t]{2}{*}{ Slovenia } & $\begin{array}{l}\text { Base: all profit from the company's } \\
\text { activities, reduced by the amount of costs } \\
\text { associated with its activities }\end{array}$ & \multirow{2}{*}{$\begin{array}{l}0 \% \text { (some funds, pension insurance companies, } \\
\text { venture capital companies). } \\
\text { Taxpayers whose profit for the previous year } \\
\text { did not exceed EUR } 50,000 \text { and EUR } 100,000 \\
\text { (if the company employs at least one full-time } \\
\text { employee for at least five months), can decide } \\
\text { on a one-time deduction equal to } 80 \% \text { of the } \\
\text { annual income, instead of the actual expenses }\end{array}$} \\
\hline & Rate: $19 \%$ & \\
\hline \multirow[t]{2}{*}{$\begin{array}{l}\text { Czech } \\
\text { Republic }\end{array}$} & $\begin{array}{l}\text { Base: taxable profit is calculated in } \\
\text { accordance with Czech accounting rules, } \\
\text { with adjustments for tax purposes. } \\
\text { In general, all expenses incurred to generate, } \\
\text { secure and maintain taxable income are } \\
\text { deductible if documented by the taxpayer }\end{array}$ & \multirow[t]{2}{*}{$\begin{array}{l}5 \% \text { - investment funds; } \\
0 \% \text { - some types of pension funds. }\end{array}$} \\
\hline & Rate: $19 \%$ & \\
\hline \multirow[t]{2}{*}{ Estonia } & Base: Distributed Profit & \multirow{2}{*}{$\begin{array}{l}\text { From } 1 \text { January } 2019 \text {, a reduced rate of } 14 \% \\
\text { has been introduced for regular dividend } \\
\text { payments (that is, distributed profits that do not } \\
\text { exceed the average taxable amount of dividends } \\
\text { distributed over the previous three years, } \\
\text { calculated at the level of the recipient of the } \\
\text { dividend). }\end{array}$} \\
\hline & $\begin{array}{l}\text { Rate: } 20 / 80 \text { of net profit distribution (or } \\
20 \% \text { of gross profit) }\end{array}$ & \\
\hline \multirow[t]{2}{*}{ Latvia } & Base: Distributed Profit & \multirow[b]{2}{*}{$\begin{array}{l}\text { Distributed profits are subject to } 25 \% \text { taxation } \\
\text { and include: declared dividends, interim } \\
\text { dividends, payments similar to dividends, } \\
\text { implicit distribution of profits and distribution } \\
\text { of estimated profits such as non-operating } \\
\text { expenses, excessive interest payments, loans to } \\
\text { related parties, transfer pricing adjustments, } \\
\text { unqualified bad debts and liquidation proceeds }\end{array}$} \\
\hline & Rate: $20 \%$ & \\
\hline \multirow[t]{2}{*}{ Slovakia } & $\begin{array}{l}\text { Base: balance sheet profit of the company, } \\
\text { adjusted for deductions and non-taxable } \\
\text { items }\end{array}$ & \multirow[t]{2}{*}{-} \\
\hline & Rate: $21 \%$ & \\
\hline \multirow[t]{2}{*}{ Spain } & $\begin{array}{l}\text { Base: global income minus deductible } \\
\text { expenses }\end{array}$ & \multirow[t]{2}{*}{$30 \%$ - rate for banks } \\
\hline & Rate: $25 \%$ & \\
\hline \multirow[t]{2}{*}{ Italy } & $\begin{array}{l}\text { Base: resident company - profit from trading } \\
\text { activities, consisting of net profit for the } \\
\text { financial year, passive income, capital gains }\end{array}$ & \multirow[t]{2}{*}{ Dormant company - $34.5 \%$} \\
\hline & Rate: $24.0 \%+3.9 \%$ (regional tax) & \\
\hline \multirow[t]{2}{*}{ France } & Base: ledger income & \multirow{2}{*}{$\begin{array}{l}\text { Reduced rates: } \\
-28.00 \% \text { - applies to the first EUR } 500,000 \text { of } \\
\text { taxable income; } \\
-33.33 \% \text { - for companies whose income is } 250 \\
\text { million EUR and more }\end{array}$} \\
\hline & $\begin{array}{l}\text { Rate: } 31 \% \text { - for companies whose turnover } \\
\text { is below } 250 \text { million EUR }\end{array}$ & \\
\hline
\end{tabular}


Another method of combating unfair tax competition is to provide the Organization for Economic Cooperation and Development countries with advice on how to counter this phenomenon [12].

The Organization for Economic Cooperation and Development identifies three main recommendations. The first recommendation is related to the formation of national legislation of states [13]. The second concerns international tax treaties, especially bilateral agreements on the avoidance of double taxation, agreements on the exchange of information and the interaction of tax authorities. In addition, treaties cannot be used by offshore companies, and countries of the Organization for Economic Cooperation and Development refuse to sign any agreements with jurisdictions that are accused of unfair tax competition. The third recommendation is aimed at developing international cooperation [14].

The main and most effective method of the Organization for Economic Cooperation and Development 's fight against unfair tax competition is moral influence by adding them to the "black" list of countries, and this is far from the best reflected on the country's image. In addition to the Organization for Economic Cooperation and Development, the Financial Action Task Force on Money Laundering is involved in the fight against tax dumping, which has published 40 recommendations for offshore zones to eliminate a number of negative phenomena, for example, money laundering, tax evasion and the financing of terrorism [15].

Despite the fact that tax competition is considered unfair among the Organization for Economic Cooperation and Development countries, in the world, among countries that are not members of this organization, low tax rates are a distinctive feature caused not only by high taxes in the United States and the European Union, but also by restrictive tax laws. It is generally accepted that it is offshore companies that are to blame for the withdrawal of assets, including monetary ones, from the territories of onshore states through the use of offshore schemes.

According to experts, unfair tax competition arose as a result of the desire of offshore countries to achieve economic stability, that is, to have sufficient funds to finance social infrastructure and industry. In addition, this phenomenon affects other aspects: international trade, gender equality and sustainable development of society, social inequality and international relations, effective investment management.

\section{Conclusion}

Thus, in relation to unfair tax competition, two main groups have emerged. The former is of the opinion that tax unification will necessitate tax cuts, which may lead to problems for some countries in the inability to support and thus finance social development programs. Others believe that tax competition will push some states to implement competitive tax structures, which will not only achieve budget equilibrium in the near future, but also ensure high employment growth in the future.

\section{References}

1. P. Heimberger, EJOEAO (2021)

2. Ya. Deng, D. You, Ya. Zhang, SP\&C (2021)

3. K. Kawachi, H. Ogawa, T. Susa, IRE\&F (2020)

4. M. Mardan, M. Stimmelmayr, JDE (2020)

5. C. Azémar, R. Desbordes, I. Wooton, JCE (2020)

6. J. P. Choi, T. Furusawa, J. Ishikawa, JIE (2020)

7. A. Haupt, T. Krieger, JUE (2019) 
8. M. Brülhart, M. Jametti, JPE (2019)

9. G. Rota-Graziosi, JME (2019)

10. A. Sharma, R. Pal, IRE\&F (2019)

11. J. Bian, X. Zhao, EJOR (2019)

12. A. A. Kalinina, ETL, 3, 12 (2014)

13. T. A. Kryakina, G. F. Tselniker, MS, 11-3, 102 (2019)

14. M. A. Mironova, A. A. Shahmametev, QE\&L, 117, 27 (2018)

15. E. K. Simakova, E2020: TQ\&MACPIIIISC, 89 (2020) 